\title{
Social Performance of Rural Bank: Impact of Commercialization
}

\section{Factors}

\section{Hesi Eka Puteri}

Faculty of Islamic Economics and Business, IAIN Bukittinggi, Bukittinggi, Indonesia

\section{Info Article}

History Article:

Submitted 20 January 2020

Revised 2 March 2020

Accepted 31 March 2020

Keywords:

Commercialization; Social

Performance; Rural Banks.

\begin{abstract}
Although social performance is an important target in islamic rural bank, this performance is constrained by various factors of commercialization. This study examined the impact of commercialization factors covering profitability, regulation, and competition on the social performance of rural bank. This research was quantitative that based on a survey on fifty units of rural banks in West Sumatera province of Indonesia from 2016 to 2018. The secondary data collected from the publication of financial services authority and other financial documents at rural banks then analyzed with panel data regression. The findings of this research showed that profitability and competition influenced the social performance, meanwhile regulation could not predict the achievement of social performance. This finding reinforced the previous studies which identified the impact of some commercialization indicators towards the achievement of social performance but there was no regulation's impact on social performance. The impact of regulation which was originally expected to be able to strengthen the social responsibility mission of rural banks evidently did not stimulate the increase of social performance.
\end{abstract}

\section{Kinerja Sosial Bank Perkreditan Rakyat: Dampak Faktor-Faktor Komersialisasi}

\begin{abstract}
Abstrak
Meskipun kinerja sosial adalah target yang penting di BPR, namun kinerja ini terkendala karena berbagai faktor komersialisasi. Studi ini meneliti dampak dari faktor komersialisasi yang meliputi profitabilitas, regulasi dan kompetisi terhadap kinerja sosial Bank Perkreditan Rakyat (BPR). Penelitian ini adalah penelitian kuantitatif berdasarkan survei pada lima puluh unit $B P R$ di provinsi sumatera barat Indonesia pada tahun 2016 hingga 2018. Data sekunder dikumpulkan dari publikasi pada otoritas jasa keuangan dan dokumen keuangan lainnya di BPR kemudian dianalisis dengan regresi data panel. Temuan penelitian ini menunjukkan bahwa profitabilitas dan kompetisi berpengaruh terhadap capaian kinerja sosial, sedangkan regulasi tidak dapat memprediksi pencapaian kinerja sosial. Temuan ini memperkuat studi sebelumnya yang mengidentifikasi dampak dari beberapa indikator komersialisasi terhadap pencapaian kinerja sosial, tetapi tidak dapat disimpulkan adanya dampak regulasi terhadap kinerja sosial. Dampak regulasi yang semula diharapkan mampu memperkuat misi tanggung jawab sosial $B P R$, ternyata tidak merangsang peningkatan kinerja sosial.
\end{abstract}

JEL Classification: G21 G30

How to Cite: Puteri, H. E. (2020). Social Performance of Rural Bank: Impact of Commercialization Factors. Jurnal Dinamika Manajemen, 11(1), 116-126. 
Hesi Eka Puteri/ Social Performance of Rural Bank: Impact of ...

\section{INTRODUCTION}

Banks are formal microfinance institutions (MFIs), which are always committed providing capital access to micro and small sectors and local communities, especially in rural areas. Likewise other kinds of microfinance institution, rural banks were designed not only for poor people but have to be able to sustain financially, cause this microfinance institution are not subsidized by the government. The rural bank has two types of performance targets, namely financial performance which focus on profitability and social performance which refers to condition about how far the financial institutions able to serve the low-income community (Mersland \& Strøm, 2014).

Social performance must be in line with financial performance (Amelec \& Carmen, 2015), but the problem that often occurs at rural banks is the difficulty in achieving these two targets simultaneously. It was observed that there were several rural banks with the good financial performance or good financial sustainability but only have a small number of clients. On the other hand, there were rural banks that capable enough to extend their outreach with a large number of clients, but their financial performance was not good enough. At several rural banks, the tradeoff between these two targets sometimes appears (Cull et al., 2011; Kipesha \& Zhang, 2013; Abdulai \& Tewari, 2017; Huq et al., 2017). However, some previous studies showed that the two aim of MFIs could be achieved at the same time (Arsyad, 2008; Bassem, 2012; Zerai \& Rani, 2012; Gakhar \& Meetu, 2013; Qinlan \& Izumida, 2013; Lebovics et al., 2016; Caserta et al., 2018)

Commercialization factors have been identified as the cause of the difference in achievement of social performance at MFIs (Zerai \& Rani, 2012; Qinlan \& Izumida, 2013; Kaur, 2014; Gashayie, 2015). One of the very popular commercialization factors is profitability. Theoretically, there is a link between profitability and outreach, because the decision of a bank to get into a certain market segment is driven by the expected profitability of that segment (Bresnahan
\& Reiss, 1991). Some previous studies which used Return on Assets (ROA) as a proxy for profitability (Kipesha \& Zhang, 2013; Piot-lepetit \& Nzongang, 2014) concluded that profitability had the negative effect on outreach to the poor, then indicating the presence of trade-off (Hermes \& Lensink, 2011; Kipesha \& Zhang, 2013).

Furthermore, Capital Adequacy Ratio (CAR) as a proxy for regulation played an important role in expanding the outreach and ensuring its sustainability. Many previous studies have linked the capital structure to financial performance, but not to analyze the impact on social performance. Axmann (2015) concluded that changing the business model due to regulations led to higher costs per dollar lent and resulted in outreach. As an engine or bumper, capital serves to overcome the incident of a shock and avoid bankruptcy (Cull et al., 2011; Gwasi \& Ngambi, 2014).

Competition in Rural Banks was also identified as another factor for MFI sustainability and it could encourage the creation of product differentiation with interest rates as an instrument. The excellence in competing through competitive interest rates or financing margins can expand the outreach of MFIs (Adams \& Tewarib, 2017). There was a significant negative effect between competition and outreach (Olsen, 2010; Assefa et al., 2013; De Cloet \& Moyaert, 2014). The increase of competition can reduce the number of clients and competition causes MFIs to be inefficient, but on the other hand, other studies have shown that although the competition effect was negative on financial self-sufficiency, it did not limit the extent of outreach.

This study aimed to examine the impact of commercialization factors covering profitability, regulation, and competition on the social performance of rural banks in West Sumatera Province. This study was interesting to analyze because of the inconsistency of the previous findings, some of the commercialization factors had a impact on social performance achievements, but some did not. Some MFIs with good financial performance also have good social performance, but some others did not. Taking the case at MFIs under the 
institutionalist approach and unsubsidized by the government such as rural banks, would give a new perspective about the link between profitability, regulation, and competition to the social performance. This is a kind of a policy study about the development of rural bank which sooner or later will be marginalized because of competition and regulation. This research will reveal the reason why the social function run well at some rural banks in one hand but fail at others, and reveals what factors influenced it.

This research is expected to reveal the reasons why the social function runs well at some rural banks but fails at others, and reveals what factors influence it. Thus, this study can respond to the inconsistencies of previous findings of the relationship between the factors of commercialization and social performance of rural banks. This study will also clarify how the relationship between these variables in rural banks, a kind of microfinance that operates under the institutionalist approach. This is something that was rarely highlighted in previous studies because they more often analyzed the social performance of microfinance with the welfares approach.

\section{Hypothesis Development \\ Relationship between Profitability and So- cial Performance}

Social performance is reflected in the form of how far the role of microfinance institutions to economic development or how far MFIs have achieved their goals to give the social benefit to poor people, which is measured with outreach. Social performance in MFIs refers to the condition about how far the financial institutions able to serve the low-income community and excluded by formal financial institutions (Mersland \& Strøm, 2014) or this refers to the final assessment of the ability of microfinance institutions to run their social mission, that is to overcome poverty. For microfinance institutions, social performance defined as the effective translation of the MFI's social mission into practice which includes increasing outreach, improving the economic and social conditions of clients and enhancing social responsibility of MFI towards clients, employees and the community (Hashemi \& Anand, 2007). The main objective of microfinance institution is to overcome poverty through lending or other financial services which grant the poor peoples and other productive sectors go together sustainably. Actually, all people are entrepreneurs but most of them do not have the opportunity to get financial support from financial institutions, so that they can free themselves from poverty and have contributed to economic development (Bateman, 2014).

Social performance is not equal to social impact such as the change in welfare among clients. Social performance is defined as the effective transference of an MFI's social mission into practice, such as increasing outreach, bettering economic and social conditions of clients and enhancing social responsibility of MFI towards the community (Hashemi \& Anand, 2007). Social performance can be measured by the outreach and the impact assessment of a program towards a community. Although these two indicators can be measured, outreach is more popular to be used to reflect how far the influence of MFIs on economic development, or how far MFIs have reached their goal in providing social benefits for the poor community (Yaron \& Benjamin, 1997; Schreiner, 2002). This indicator can function as the best proxy about how far an MFI has achieved its goal of providing social benefits for the poor people.

Social performance in the microfinance literature is principally noticed in terms of outreach. Although outreach is noted as a multidimensional concept, but this concept generally refers to the number of clients served. Outreach is defined as an effort to expand microfinance services for people who are not served by financial institutions or the extent to which an MFI has succeeded in achieving client targets for financial services (Yaron \& Benjamin, 1997). Outreach is classified as the efforts to extend microfinance services to the people who are underserved by financial institutions, which can be measured in terms of breadth by using the number of clients served or by the depth by using the socio-economic level of clients that MFIs can be reached 
Hesi Eka Puteri/ Social Performance of Rural Bank: Impact of ...

(Lafourcade et al., 2005; Rao \& Fitamo, 2014). Two popular aspects of outreach were the depth of outreach and the breadth of outreach (Rhyne, 1998). Both of them refer to the poverty level of the clients served and the number of people served by the MFIs. Both of these concepts are widely used in the literature of microfinance institutions as a measure of the social performance of a microfinance institution.

The topic of commercialization in microfinance was carried out by Christen for the first time, which discussed that the commercial approach was made up of three main principles, which were profitability, competition, and regulation (Christen et al., 2002). This issue becomes even more interesting because the commercialization causes the "mission drift" to appear, where microfinance institutions more prefer to target the richer group of the society rather than the poor class. The evolution of this issue finally leads to three main aspects such as profitability, competition and regulation are interesting to be tested and debated.

First, Profitability as part of the aspects of commercialization, profitability is introduced as the ability of the company to make a profit by utilizing the total assets owned by the company after adjusting for all costs. Return on Assets (ROA) is one measurement that represents it in MFIs. The bigger the ratio of ROA, the more profit a rural bank can make and it also indicates the indicator of the operational efficiency of Rural Banks. Previous studies have used ROA as a proxy for profitability for MFIs (Kipesha \& Zhang, 2013; Piotlepetit \& Nzongang, 2014) and concluded that profitability had the negative effect on outreach to the poor, then indicating the presence of tradeoff (Hermes \& Lensink, 201 1; Kipesha \& Zhang, 2013). Theoretically, there is a link between profitability and outreach, because the decision of a bank to get into a certain market segment is driven by the expected profitability of that segment (Bresnahan \& Reiss, 1991). If a financial institution predicts some profits from the market to be entered, then the financial institution will consider entering the intended market share and thereby expand its outreach.
H1: Profitability has a positive impact on the social performance of the rural banks.

\section{Relationship between Regulation and Social Performance}

Second, regulation. The regulatory factor in rural banks refers to the ability of rural banks to carry out the intermediary's function, namely the function of banks as recipients of deposits and channeling them to the client. The ratio used for a proxy is the Capital Adequacy Ratio (CAR), because the Capital Adequacy Ratio (CAR) has a major influence on lending and ensuring the sustainability of financial institutions. Many previous studies have linked the capital structure to financial performance, but not many have seen the impact on social performance.

CAR played an important role in expanding the MFI network and ensuring its sustainability and capital adequacy was an important factor in the sustainability of any kind of business organization that used public money such as banking. Concluded that changing the business pattern due to regulations led to higher costs per dollar lent and resulted in outreach. The main function of capital is to serve, as loan support if a possible loss arises (Axmann, 2015). Capital is useful as an "engine and bumper" for MFIs in the event of a shock. The better the capital, the more able a financial institution will face losses and avoid bankruptcy and competition had a positive effect on financial performance (Cull et al., 2011; Gwasi \& Ngambi, 2014).

$\mathrm{H} 2$ : Regulation has a positive impact on the social performance of the rural banks.

\section{Relationship between Competition and So- cial Performance}

Third, competition. An aspect of competition in Rural Banks indicates to its ability to compete and survive in providing microfinance services and competition encouraged the creation of product differentiation with interest rates as an instrument and also a major determinant for MFI sustainability (Casini, 2008). Furthermore, the excellence in competing through competitive interest rates 
or financing margins can expand the outreach of MFIs (Adams \& Tewarib, 2017) and there was a significant negative effect between competition and outreach (Olsen, 2010; Assefa et al., 2013; De Cloet \& Moyaert, 2014). The increase in competition can reduce the number of clients and competition causes MFIs to be inefficient. However, several other studies have shown that although the competition effect was negative on financial self-sufficiency, it did not limit the extent of outreach.

H3: Competition has a negative impact on the social performance of the rural banks.

\section{METHOD}

\section{Research Design}

This study was field research with a quantitative approach. This study was conducted at fifty rural banks in west Sumatera province from 2016 to 2018. To examine the impact of commercialization factors on the social performance of rural banks, this study adopted panel data regression models.

\section{Population and Sample}

The population of this study was rural banks in West Sumatera Province of Indonesia from 2016 to 2018, which consists of $99 \mathrm{Ru}$ ral Banks with 7 units including Islamic Rural Banks. The sample size of this research were 50 units of rural banks, were chosen purposively according to the research needs. This study applied sampling area that included four districts and two cities which selected purposively, consist of Agam district, Lima Puluh Kota District, Tanah Datar District, West Pasaman District, Sawahlunto City and Solok City. A total of 50 units of rural banks in this area were sampled for the study. The reason for choosing this area as a sample was due to the likeness of socio-demographic conditions and the allocation of Rural Banks in this area was better than others. The data in this study came from the secondary data, which got from the audited financial report published by the Financial Services Authority and financial report at Rural Banks itself.

\section{Variable and Measurement.}

The dependent variable in this research is social performance, proxied by the number of clients (Schreiner, 2002; Huq et al., 2017). The independent variables in the model are profitability which proxied with Return on Assets, the regulation which proxied with Capital Adequacy Ratio and competition which proxied with the prime lending rate (De Cloet \& Moyaert, 2014; Gwasi \& Ngambi, 2014; Axmann, 2015; Johnson, 2015; Quayes, 2015).

\section{Data Analysis Method}

This study estimated the impact of commercialization factors consisting of profitability, regulation, and competition to the social performance of MFIs. The panel regression method was used in analyzing the empirical model. The functional equation that will be estimated is as follows:

NOCit $=\beta 0+\beta 1$ ROAit $+\beta 2$ CARit $+\beta 3$ Rateit $+\mathcal{E}_{\text {it }}$

Notes:

NOC : the number of clients (a proxy for social performance),

ROA : Return on Assets (a proxy for profitability),

CAR : Capital Adequacy Ratio (a proxy for regulation) and

Rate : the prime lending rate (a proxy for competition).

To predict the value of constant and regression coefficient, the panel data regression method considered three models, namely pooled least squared (PLS), fixed effect model (FEM) and random effect model (REM). Model selection was done with a chow test to choose a choice between pooled least squared (PLS) and fixed effect models, Breusch Pagan Lagrange Multiplier (LM) test to choose a pooled least squared (PLS) or random-effect model. Finally, the Hausman test was a choice among the fixed effect model or the random-effect model. After obtaining the best model, the next step of testing was done by doing the F-test, t-test, and RSquared to see the effect of independent variables on the dependent variable. 
Hesi Eka Puteri/ Social Performance of Rural Bank: Impact of ...

\section{RESULT AND DISCUSSION}

To answer the research hypothesis, the analysis of the causal relationship between profitability, regulation, and competition to social performance of MFIs was implemented and panel data regression in this study was conducted with three model estimation methods, namely pooled least squared (PLS), fixed-effect model, and random effect model. All the estimation of panel data regression presented in Table 1.
The results of the Chow test showed the Probability $>\mathrm{F}=0.000$, which meant of refusing the PLS model and accepted the Fixed Effect Model. Breusch Pagan Lagrange Multiplier (LM) test also resumed that Probability $>\mathrm{F}=0.000$, which also meant the refusing of the PLS model and decided to use the Random Effect Model. Furthermore, The Hausman test was applied for testing between the fixed effect model and the random effect model, which then appeared with Probability $>\mathrm{F}=0.6053$.

Table 1. Model Estimation with Panel Data Regression

\begin{tabular}{llrl}
\hline Model & Var. & t-Statistic or z-Statistic & Prob. \\
\hline Pooled least squared (PLS) & Cons & 5.34 & .000 \\
Prob $>$ F $=.000$ & ROA & 4.33 & .000 \\
R-Squared $=.3189$ & CAR & -2.43 & .016 \\
& Rate & -4.19 & .000 \\
\hline Fixed Effect Model (FEM) & Cons & .37 & .711 \\
Prob $>$ F $=.0601$ & ROA & 2.34 & .021 \\
R-Squared $=.3189$ & CAR & 1.01 & .315 \\
& Rate & .01 & .412 \\
\hline Random Effect Model $($ REM $)$ & Cons & 4.66 & .000 \\
Prob $>$ chi2 $=.0003$ & ROA & 2.25 & .024 \\
R-Squared $=.2353$ & CAR & -.56 & .574 \\
& Rate & -3.17 & .002 \\
\hline
\end{tabular}

After obtaining the estimation results from the three alternative models consisting of PLS, Fixed Effect Model and Random Effect Model, then to determine which model will be chosen, several tests were applied. Some of the tests that will be carried out covering the Chow test, LM Test and Hausman Test, as shown in Table 2.

Table 2. Selection of Panel Data Regression Model

\begin{tabular}{l|l}
\hline Model Estimation & Probability \\
\hline Chow Test & .0000 \\
Breusch Pagan Lagrange & .0000 \\
Multiplier (LM) test & \\
Hausman Test & .6053 \\
\hline
\end{tabular}

The results showed a significant impact of profitability, regulation and competition on social performance (Probability $>\mathrm{Chi}^{2}=0.0003$ ). Overall, the results of the panel regression with the random effect model was quite good and fulfilled the criteria statistically (Probability $>\mathrm{Chi}^{2}$ $=0.0003$, R-Squared $=0.2353$ ).

Furthermore, to test the hypotheses in this study, it can be seen from the results of the z-statistic in Table 3. The estimation coefficient represented that there was a positive influence between profitability which proxied by ROA on the social performance $($ Coefficient $=19.13907$, p-value $=0.024)$. Thus, H1: Profitability is positively associated with social performance was acceptable. The increase in ROA causes an increase in the number of clients of Rural Bank. 
Thus, an increase in the profitability of Rural Banks can affect the increase in the social performance of Rural Bank. Thus, the model used is the Random Effect Model, as in Table 3. which results in a reduction in the social performance of MFIs.

To strengthen the analysis of the findings in Table 3, the model was re-examined using

Table 3. Panel Regression with Random Effect Model

\begin{tabular}{lrccl}
\hline Variable & Coefficient & Standard Error & z-Statistic & Prob. \\
\hline Profitability & 19.13907 & 8.49179 & 2.25 & .024 \\
Regulation & -3.48685 & 6.20185 & -.56 & .574 \\
Competition & -141.78470 & 44.71457 & -3.17 & .002 \\
Constant & 3000.28400 & 643.58610 & 4.66 & .000 \\
\hline
\end{tabular}

Prob $>$ Chi $2=0.0003, \mathrm{R}^{2}=0.2353$

Next, it can also be concluded that there was no significant impact of regulation which proxied with CAR on the social performance of Rural Bank (Coefficient $=-3.48685$, -value $=$ 0.574). Rural Bank's financial ability to increase its Capital Adequacy Ratio (CAR) as a proxy stepwise regression for observing the strength of each variable. The results of stepwise multiple regression analysis showed the best predictors in the model were profitability and competition, while regulation was excluded from the model, as in Table 4.

Table 4 The Result of Stepwise Multiple Regression Analysis

\begin{tabular}{lrrrc}
\hline Variable & Coefficient & Standard Error & t-Statistic & Prob. \\
\hline Profitability & 262.7355 & 66.07058 & 3.98 & .000 \\
Competition & -132.4813 & 24.01691 & -5.52 & .000 \\
Constant & 2281.3410 & 412.12100 & 5.54 & .000 \\
\hline
\end{tabular}

Prob $>\mathrm{F}=0.0000$

F test $=28.82$

R-Squared $=0.2902$

for regulation does not affect the increase of the number of clients. In other words, regulation did not affect the social performance of MFIs.

$\mathrm{H} 2$ : Regulation is positively associated to the social performance of Rural Bank, it was rejected. Increasing regulation proxied with CAR does not affect the increase of the number of clients of Rural Banks. Thus, strengthening the regulation of rural banks does not affect their social performance.

Furthermore, the estimated coefficient of $-141.78470(p$-value $=0.002)$ showed that competition which proxied by the prime lending rate had negative effect on the social performance of Rural Bank. Thus, H3: competition is negatively associated with the social performance of Rural Bank, acceptable. The higher the prime lending rate causes a decrease in the number of clients,
The results of the stepwise regression were quite good and fulfilled the criteria statistically (Probability $>\mathrm{F}=0.0000$, F-Test $=28.82$ and R-Squared $=0.2902$ ). The estimated coefficient indicated that there was a positive effect of profitability on social performance (Coefficient $=262.7355, \mathrm{p}$-value $=0.000)$. Also observed a negative influence between competition on social performance (coefficient $=-132.4813, \mathrm{p}$ value $=0.000)$. Thus, this result reinforced the analysis of findings on the random-effect model that showed the significant impact of profitability and competition on the social performance of rural banks.

The findings of this research revealed that the commercialization factors such as profitability, regulation, and competition as the determinants about how far the social performance of 
rural banks, has been proven empirically. This finding emphasized the role of microfinance institutions towards economic development was strongly influenced by the financial sustainability of the institution. Microfinance institutions can attain their dual objectives and also fulfill their "ultimate promise" of social performance and financial performance, if several determinants can be managed precisely. This finding reinforced some previous studies that showed the two aims of MFIs could be achieved at the same time (Arsyad, 2008; Zerai \& Rani, 2012; Gakhar \& Meetu, 2013; Qinlan \& Izumida, 2013; Lebovics et al., 2016; Caserta et al., 2018).

Testing the relationship between profitability and social performance in rural banks, produced the findings that were not much different. Rural banks will only strengthen their social performance if only their financial performance is also strong, especially profitability. Likewise, other kinds of microfinance institution, rural banks which are designed not only for poor people and not subsidized by the government, will be able to provide their social performance if only they sustain financially. Profitability, as an indicator the self-sufficiency in financial, has been indicated as a determinant of the social performance of rural banks. The higher the profitability of a financial institution, the more able the ability of banks to carry out their social functions by channeling loans at a lower average rate.

Theoretically, a loan with a small average is assumed to increase operating costs, and this will only be done by rural banks with high profitability. Thus, the higher the profitability, the easier it will be for banks to carry out their social functions. This finding contradicted with the previous studies (Kipesha \& Zhang, 2013; Abdulai \& Tewari, 2017; Huq et al., 2017) that concluded the negative connection between Return on Assets (ROA) with "outreach", one of the indicator for the social function. Thus, this research concluded that the two aims of MFIs could be achieved at the same time, and there is no trade-off between profitability and the achievement of social function for rural banks.
Although profitability has been proven to be able to improve the social performance of rural banks, but not with regulation. This finding showed that regulation does not affect the improving of social performance. Even though regulations have been made by the government such as the requirement for rural banks to become a capital adequacy ratio, which serves to prepare the risk of losses that may be faced by banks, it does not guarantee rural banks will improve their social performance. Requirements to maintain the bank's adequacy ratio play a role in maintaining the capital structure, but not to increase the volume of credit extended by banks. The different proxies used, lead to different findings that prove the absence of the relationship between regulation and social performance. Previous assumptions that the greater the capital, the better the social performance, is not proven in this case. The capital structure might regenerate the efficiency of MFIs and also financial sustainability (Bogan, 2012), but it does not guarantee the improvement in the social function of a rural bank.

Previous studies that revealed the influence of competition on social performance (Adams \& Tewarib, 2017), also proved to be in line with this finding. Competitive interest rates or financing margins can be expanded the outreach of rural banks. Competitive interest rates are still a consideration for prospective customers to transact in rural areas or other financial institutions. rural bank segmentation which is also entered by banks that are stronger in the capital structure is also expected to further worsen the social performance of rural banks if there are no regulations to support it. This finding requires further analysis for verification. This finding is relevant to the previous studies that also found a significant negative effect between competition and outreach at MFIs (Olsen, 2010; De Cloet \& Moyaert, 2014). The higher prime lending rate will result in fewer clients, which means rural banks are unable to fulfill their social functions. Rural banks, which are non-subsidized microfinance institutions, are greatly affected by the prime lending rate. On one hand, banks 
are highly profitable if interest rates are high. But on the other hand, high interest resulted in rural banks being abandoned by clients. This finding has implications for the importance of the economic efficiency in rural banks. It will be difficult to declare rural banks as community banking and support development in rural areas if the interest rates applied are still high enough.

\section{CONCLUSION AND RECOMMENDATION}

It can be concluded that the policy to expand the outreach to the community as an effort to improve the social performance of rural banks can be done by strengthening their commercialization factors. The efforts to increase profitability can increase social performance, as well as reduce the prime lending rate. Both of these policies can be best solutions to improve the social performance of rural banks, for making rural banks more than just a profit-oriented financial institution but also able to become community banking, especially for poor peoples in rural areas. However, the previous assumption that the greater the capital, the better the social performance, is not proven in this case. The capital structure might improve financial sustainability, but it does not guarantee an improvement in the social performance of a rural bank.

Although this study has tried to analyze the impact of commercialization factors empirically with a more realistic model, this study is not without its limitations. Despite of the finding that has been able to explain empirically the impact of commercialization factors, but it still needs to be elaborated for more cases in rural banks. The limitation of this study is in the analysis unit, because there were only $50 \mathrm{Ru}$ ral Banks in West Sumatera province that were analyzed from 2016 to 2018 due to the limited availability of financial data. As well as the measurement of social performance, which is only limited to the number of clients. Although the concept of social performance has a multidimensional concept, this study limits the analysis of social performance to the concept of outreach. However, it can be proposed from the fin- dings of this study that social performance on rural banks is highly dependent on the conditions of its commercialization factors. For future research, we suggest to test the performance of social performance in more cases with a more comprehensive unit of analysis. Future studies can also be carried out by expanding the determinants of social performance achievements, so that there are developments in existing theories. Apart from the above limitations, we believe this investigation has more evidence and the distinction in the study of social performance of rural banks as one type of microfinance institution with an institutionalist approach.

\section{REFERENCES}

Abdulai, A., \& Tewari, D. D. (2017). Trade-off between Outreach and Sustainability of Microfinance Institutions: Evidence from SubSaharan Africa. Enterprise Development and Microfinance, 28(3), 162-181.

Adams, A., \& Tewarib, D. D. (2017). Determinants of Microfinance Outreach in Sub-Saharan Africa: a Panel Approach. Acta Commercii, 17(1), 1-10.

Amelec, V., \& Carmen, V. (2015). Relationship between Variables of Performance Social and Financial of Microfinance Institutions. Advanced Science Letters, 21(6), 1931-1934.

Arsyad, L. (2008). Microfinance Institutions, Institutional Performance and Sustainability. Yogyakarta: Andi Offset.

Assefa, E., Hermes, N., \& Meesters, A. (2013). Competition and the Performance of Microfinance Institutions. Applied Financial Economics, 23(9), 767-782.

Axmann, N. (2015). What is the Effect of Regulatory Supervision on the Profitability and Outreach of Microfinance Institutions?. Southeast Asian Journal of Economics, 3(1), 1-25.

Bassem, B. E. N. S. (2012). Social and Financial Performance of Microfinance Institutions: is there a Trade-Off?. Journal of Economics and International Finance, 4(4), 92-100.

Bateman, M. (2014). The Rise and Fall of Muhammad Yunus and the Microcredit Model. Management: Leading \& Collaborating in Competitive World, 11Th. Edition. McGraw-Hill Education. 
Hesi Eka Puteri/ Social Performance of Rural Bank: Impact of ...

Bogan, V. L. (2012). Capital Structure and Sustainability: an Empirical Study of Microfinance Institutions. Review of Economics and Statistics, 94(4), 1045-1058.

Bresnahan, T. F., \& Reiss, P. C. (1991). Entry and Competition in Concentrated Markets. Journal of Political Economy, 99(5), 977-1009.

Caserta, M., Monteleone, S., \& Reito, F. (2018). The Trade-off between Profitability and Outreach in Microfinance. Economic Modelling, 72, 3141.

Casini, P. (2008). Competition and Altruism in Microcredit Markets. Thesis. Université Libre de Bruxelles, Brussels.

Christen, R. P., Drake, D., \& Rhyne, E. (2002). The Commercialization of Microfinance: Balancing Business and Development. Bloomfield: Kumarian Press.

Cull, R., Demirgüç-Kunt, A., \& Morduch, J. (2011). Microfinance Trade-offs: Regulation, Competition and Financing. The Handbook of microfinance, 41-157.

Cull, R., Demirgüç-Kunt, A., \& Morduch, J. (2011). Does Regulatory Supervision Curtail Microfinance Profitability and Outreach?. World Development, 39(6), 949-965.

De Cloet, A., \& Moyaert, H. (2014). Microfinance: Influence of Competition on Outreach. Thesis. Ghent University.

Gakhar, K., \& Meetu. (2013). Financial Performance and Outreach of Microfinance Institutions: is there a Trade-Off? - an Empirical Study of Indian. Sona Global Management Review, 7(4), 1-10.

Gashayie, A. (2015). Factors that Affect Financial Sustainability of Microfinance Institution: Literature Review. European Journal of Business and Management, 7(7), 223-229.

Gwasi, N., \& Ngambi, M. T. (2014). Competition and Performance of Microfinance Institutions in Cameroon. International Journal of Research in Social Sciences, 3(8), 1-36.

Hashemi, S., \& Anand, M. (2007). Toward a Social Performance Bottom Line in Microfinance. Available at: https://www.cgap.org/sites/ default/files/CGAP-Brief-Toward-SociaPerformance-Bottom-Line-MicrofinanceNov-2007.pdf. 15 December 2019.

Hermes, N., \& Lensink, R. (2011). Microfinance: its Impact, Outreach, and Sustainability. World Development, 39(6), 875-881.
Huq, B. I. A., Azad, M. A. K., Masum, A. K. M., Wanke, P., \& Rahman, M. A. (2017). Examining the Trade-off between Social Outreach and Financial Efficiency: Evidence from Microfinance Institutions in South Asia. Global Business Review, 18(1), 617-828.

Johnson, C. (2015). The Impacts of Capital Structure on Depth of Outreach in Sub-Saharan Africa. Critique: a Worldwide Journal of Student Politics, 118-149.

Kaur, P. (2014). Outreach and Sustainability of Microfinance Institutions in India in Pre and Post Andhra Pradesh Microfinance Crisis in Context of South Asia. Global Journal of Finance and Management, 6(6), 569-574.

Kipesha, E. F., \& Zhang, X. (2013). Sustainability, Profitability, and Outreach Tradeoffs: Evidence from Microfinance Institutions in East Africa. European Journal of Business and Management, 5(8), 136-149.

Lafourcade, A., Isern, J., Mwangi, P., \& Brown, M. (2005). Overview of the Outreach and Financial Performance of Microfinance Institutions in Africa. Microfinance Information Exchange; Washington; DC. Available at: Http://www. Mixmarket. Org/Medialibrary/Mixmar. 15 December 2019.

Lebovics, M., Hermes, N., \& Hudon, M. (2016). Are Financial and Social Efficiency Mutually Exclusive? a Case Study of Vietnamese Microfinance Institutions. Annals of Public and Cooperative Economics, 87(1), 55-77.

Mersland, R., \& Strøm, R. Ø. (2014). Microfinance Financial and Social Performance: an Introduction in Microfinance Institutions. Microfinance Institutions, 1-11. London: Palgrave Macmillah.

Millson, H. F. (2013). The Trade-off between Sustainability and Outreach: the Experience of Commercial Microfinance Institutions Department of Economics Advisor: Shannon Mudd. Doctoral Dissertation. Haverford College.

Olsen, T. D. (2010). New Actors in Microfinance Lending: the Role of Regulation and Competition in Latin America. Perspectives on Global Development and Technology, 9(3-4), 500-519.

Piot-lepetit, I., \& Nzongang, J. (2014). Financial Sustainability and Poverty Outreach Within a Network of Village Banks in Cameroon: a 
Multi-DEA Approach. European Journal of Operational Research, 234(1), 319-330.

Qinlan, Z., \& Izumida, Y. (2013). Determinants of Repayment Performance of Group Lending in China. China Agricultural Economic Review, $5(3), 328-341$.

Quayes, S. (2015). Outreach and Performance of Microfinance Institutions: a Panel Analysis. Applied Economics, 47(18), 1909-1925.

Rao, K. R. M., \& Fitamo, T. L. (2014). Concepts and Measures of Outreach and Sustainability in Microfinance Institutions: a Comprehensive Literature Review. Research Journal of Finance and Accounting, 5(21), 41-49.

Rhyne, E. (1998). The Yin and Yang of Microfi- nance: Reaching the Poor and Sustainability. Microbanking Bulletin. Issue, 2(1), 6-8.

Schreiner, M. (2002). Aspects of Outreach: a Framework for Discussion of the Social Benefits of Microfinance. Journal of International Development, 14(5), 591-603.

Yaron, J., \& Benjamin. (1997). Rural Finance: Issues, Design, and Best Practices (14). Washington DC: World Bank.

Zerai, B., \& Rani, L. (2012). Is there a Trade-Off Between Outreach and Sustainability of Microfinance Institutions? Evidence from Indian Microfinance Institutions (MFIs). European Journal of Business and Management, 4(2), 9099. 